\title{
GO FOR THE GOLD
}

\author{
FUNDRAISING FOR TEACHING CENTERS
}

\section{Mark A. Hohnstreiter, Tara Gray, New Mexico State University}

At New Mexico State University Teaching Academy, we have developed a comprebensive model to raise funds from faculty and others for our teaching center, which has resulted in a culture of giving. The payoff from a fundraising effort is huge, not only in terms of money, but in terms of the personal investment of participants, both valuable in difficult economic times. We explain in this chapter how to establish a fundraising program so that your teaching center can go for the gold.

Small budgets are one of the major challenges facing teaching centers. Although faculty developers may assume that it is the job of university advancement to do their fundraising, very few such units fundraise for departments as small as teaching centers. Thus, centers may want to initiate their own fundraising to supplement allocations from central administration.

At the New Mexico State University (NMSU) Teaching Academy, we have raised funds from university units and individuals. We reasoned that it would be easier to get some money from many sources rather than a lot from central administration and that deans would be especially supportive given their faculty's participation in our activities. In 1998, we began soliciting from deans and directors amounts ranging from $\$ 3,000$ to $\$ 20,000$ (Gray \& Conway, 2007). In 2004, we began systematic efforts to raise additional money from faculty and other interested individuals from the university community and beyond. As of 2010, our annual donations have grown to $\$ 30,000$ a year, given by more one hundred regular donors. Our center also obtained three exceptional future gifts

We thank the following people for their sage responses to earlier drafts of this chapter: Lockett Ford Ballard Jr., A. Jane Birch, Jean Conway, Ereney Hadjigeorgalis, Erika Kustra, Laura Madson, and Ben Wu. 
Figure 19. I Fundraising Plan Flowchart

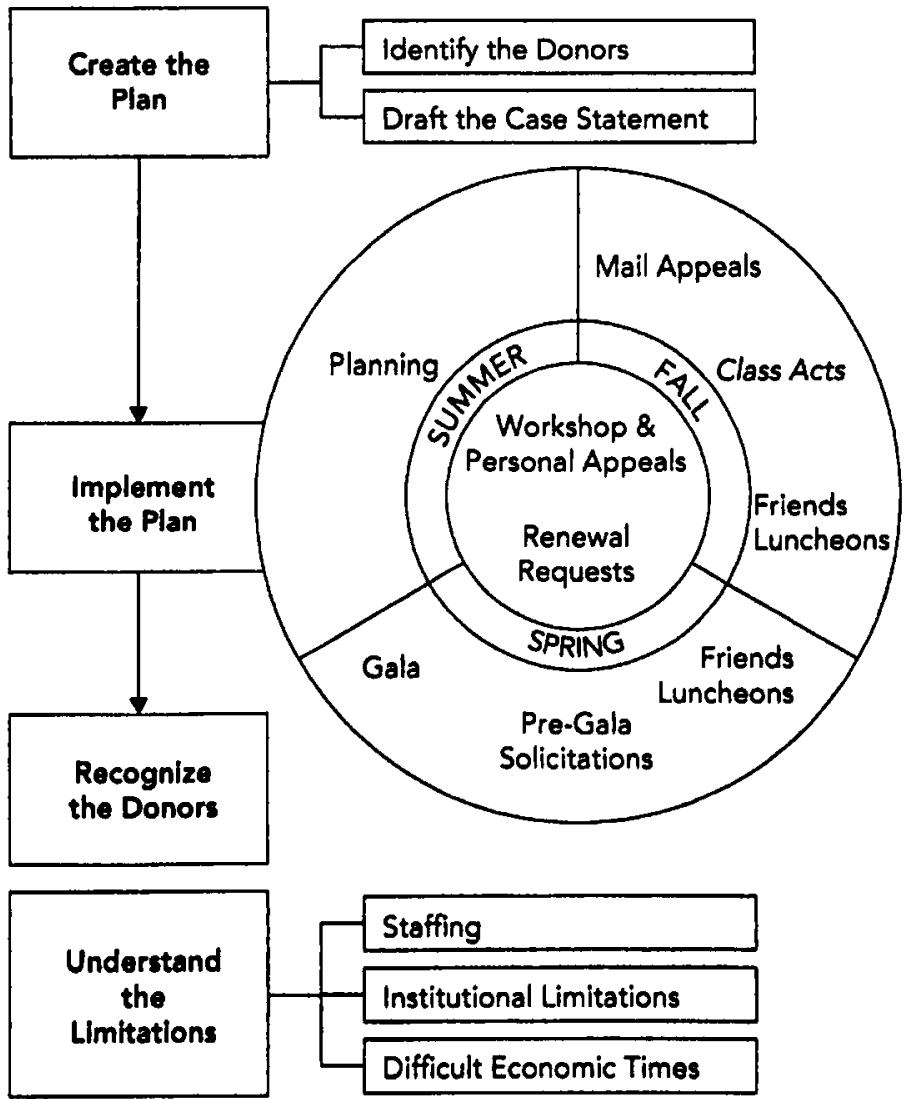

Note. Class Acts is a Teaching Academy newsletter.

totaling more than $\$ 375,000$ to start an endowment. We estimate that we have raised four times what we have spent on fundraising.

A start-up fundraising program requires thorough planning (Weinstein, 2009), as depicted in Figure 19.1. First, we identified potential donors and crafted a statement seeking their support. Second, we solicited gifts through mail appeals, personal appeals, and fundraising events. Third, we recognized donors to thank them and encourage repeat giving. The plan needed to be realistic, so we considered and addressed potential limitations.

\section{Identifying the Donors}

Identifying the right potential donors gives the fundraising plan the greatest chance of success (Sargeant \& Jay, 2004). Donors for traditional fundraising can be private individuals, corporations, foundations, 
government, and private agencies and, in the case of a teaching center, the participants themselves. At NMSU, we decided to focus first on potential donors who were nearest and dearest to our program: our members. Entry-level members are those who participate ten hours or more in Teaching Academy programming; sustaining members, twenty hours; and distinguished members, forty hours. Although most centers do not have a membership program, it is essential to identify regular participants before launching an advancement effort (Pitman, 2007). We started our fundraising program by approaching all three groups of members. Because they are on the university payroll, they had the additional option of giving through payroll deduction.

Subsequently we broadened our appeals to selected community members, including emeriti faculty, retired educators in the community, the American Association of University Women, and major university donors we happened to know well. Furthermore, we asked our board for the names of potential prospects. Three community donors made all the difference with their planned gifts of bequests (Ashton, 2004).

\section{Making the Case for Support}

Donors are savvy and will naturally question the need for giving to a teaching center as opposed to other worthwhile charities. Therefore, launching a sound advancement plan requires a succinct case for support; this is the case statement. Donors want to know why their gifts are needed, what purpose they will serve, how to give, and what amounts to give. A good case statement includes the essence of the mission and vision of the teaching center (Ahern, 2007). It tells why the teaching center is necessary and spells out opportunities rather than problems (Barbato \& Furlich, 2000). In addition, the case statement is the primary document distributed to donors and friends. Portions of its text will be used in fundraising appeals and grant applications. Finally, the process of creating the case statement creates buy-in from constituents, heightens awareness of the teaching center's needs, can overcome institutional reluctance, and may generate initial gifts (Hecht, 2008).

In the NMSU Teaching Academy case statement (Exhibit 19.1), we crafted an argument for supporting our unit, provided some statistics, and made an appeal. Our argument was threefold: (1) teaching and learning are vital components of the university mission; (2) the Teaching Academy builds community for NMSU educators through training, mentoring, and networking; and, perhaps most important, (3) the Teaching Academy ultimately benefits all university students through enhanced learning. 


\section{Exhibit 19. I Case Statement}

"Giving a student a scholarship means changing the world one student at a time; giving a teaching scholarship means changing the world many students at a time."

The NMSU Teaching Academy offers donors the opportunity to have an institution-wide impact on the NMSU campuses. Some $50 \%$ of University faculty members participate in at least one NMSU Teaching Academy activity a year. The Center provides training, networking, and mentoring to NMSU faculty, staff and graduate student teachers. It supports teachers, enhances learning, and builds community. The Teaching Academy helps educators develop extraordinary teaching lives embedded in exceptional careers. All members of the University community, especially NMSU students, benefit through enhanced learning.

Formally organized in 2003, the NMSU Teaching Academy is modeled on other successful initiatives at United States colleges and universities and is the most advanced teaching center in the state of New Mexico. The Teaching Academy serves more than 1,000 educators and provides over 8,000 hours of professional development per year. Offerings have included short courses, such as Team Mentoring and Publish \& Flourish, and workshops on teaching, learning, and distance education.

Gifts of all sizes are valuable because they provide ongoing support for the Academy. The Academy provides several significant donor opportunities, and both its director and advancement officer would be pleased to describe them in greater detail.

\section{Scholarship Support: $\$ 100,000$}

The Teaching Academy seeks scholarships for faculty to attend national teaching conferences and institutes. Such scholarships enhance teaching, which benefits all members of the University community and especially NMSU students. Many newer faculty members do not have the discretionary salary or support to otherwise attend these valuable professional development opportunities.

\section{Capital Opportunities: $\$ 250,000$}

The Teaching Academy maintains a spacious and well-equipped classroom to conduct its programs. It is the site of an event every day throughout the school year, conducted by educational leaders from NMSU and across the country. Naming the classroom would provide a donor significant recognition, as well as ensure that the room would be equipped with the latest teaching technology, including computers, projectors, and other furnishings critical to the teaching process. In addition, the Teaching Academy maintains an extensive teaching library used by NMSU educators and other participants in the Academy's programs. 
Named Endowments: \$2 million

While NMSU maintains a strong institutional commitment to its Teaching Academy, endowments would provide perpetual support and ensure that the Academy receives funding far into the future. In this way, the Academy would be permanently institutionalized in the fabric of the teaching culture at NMSU. Such endowments could include naming the Academy, or providing an endowed chair or professorship to support faculty or graduate student fellows at the Academy. The Teaching Academy has already established an endowment fund through the NMSU foundation, and gifts of any size are welcome.

Statistics are also persuasive. For example, about 50 percent of our seven hundred full-time faculty members participate in at least one NMSU Teaching Academy offering a year, and about 30 percent of the three hundred NMSU Teaching Academy members are donors. A particularly compelling appeal was borrowed from the Texas A\&M Center for Teaching Excellence: "Giving a student a scholarship means changing the world one student at a time; giving a teaching scholarship means changing the world many students at a time."

\section{Soliciting Gifts}

We seek gifts throughout the school year through mail appeals; one-onone solicitations; and pitches at workshops, Friends Luncheons, and the Teaching Academy gala. Our annual cycle of activity has become routine, making the fundraising program easier to schedule and manage. Members and other friends of the Teaching Academy receive solicitations at selected points in the academic year. Thus, prospective donors are given multiple opportunities to give, with each appeal generating new and increased givers (Greenfield, 2002).

\section{Mail Appeals}

To start our fundraising effort, a campus mail appeal (Exhibit 19.2) was sent to all past and present members (Greenfield, 2002). We developed letters of solicitation to accompany either our giving envelope (for nonuniversity employees) or the university's payroll deduction form (for faculty and staff) (Lowenstein, 1997). Payroll deduction, an automatic way of giving, proved popular with faculty and is convenient for us because many of these gifts renew from year to year. 


\section{Exhibit 19.2 Mail Appeal}

Each fall, we write to our Teaching Academy members to ask for your financial support of our efforts. The University provides us with the important core support we require to maintain our activities. To do even more, we rely on the generosity of our members.

Our donors help support scholarships to teaching workshops, new materials for our library, attracting nationally recognized speakers, and developing even more innovative programs. For example, this year we launched Tenure and Promotion Portfolios, a weeklong intensive, immersion workshop to assist faculty in documenting their greatest accomplishments in teaching, scholarship and service.

We invite you to join more than 100 of your colleagues who have already chosen to lend their support to the Teaching Center. We thank you for your kind consideration.

Our solicitation materials guide donors to give in specified amounts. Without giving categories, the tendency is for donors to make smaller gifts than they are capable of (Sargeant $\&$ Jay, 2004). The annual recognition categories we developed were based on a pay period every two weeks: backers (five dollars per pay period), builders (ten dollars per pay period), founders (twenty-five dollars per pay period), and benefactors (fifty dollars per pay period). We also give donors the option of making cash gifts outright, and we specify corresponding amounts.

Typically the advancement officer and director have jointly written our appeals. Recently we asked an enthusiastic faculty benefactor to write because changing authors draws more attention to our appeals (Ahern, 2007). We have followed the cue of many charities in asking for upgraded giving. Upgrade mailings (Exhibit 19.3) are personalized, asking our backers to become builders and our builders to become founders (we ask our founders to become benefactors in person only). Asking for upgrades has resulted in increased gifts.

\section{One-on-One Solicitations}

Of course, direct one-on-one solicitations are more successful than mail requests (Panas, 2002). In fact, peer-to-peer conversations can be among the most effective tools fundraisers have available (Reid, 1998). Resources are readily available to guide volunteers and new fundraisers in these solicitations. A faculty developer who does not feel comfortable 


\section{Exhibit 19.3 Upgrade Letter}

We value your financial support of our Teaching Academy. You are demonstrating your commitment to our important work of training, mentoring, and networking with your regular gift of $\$ \mathrm{XX} /$ month.

We appreciate your generosity and we would like to ask you to consider increasing your support to help us in what may be our most challenging financial year. Like many units of the University, and especially smaller ones like ours, we face challenging times. As you well know, NMSU has had to make difficult decisions about its support of various colleges, departments, and centers.

The Teaching Academy is no exception to budget reduction. We have had to make several difficult decisions. In the past we have funded travel for faculty to attend national conferences, such as Boot Camp for Profs and the Madison Distance Education Conference. We have featured many national speakers, the most popular being Larry Michaelsen (Team-Based Learning) and Meggin McIntosh (Time Management). More than 50 faculty and staff attended our grant-writing workshops mentored by Ron Stewart. And we have offered stipends to participants in our short courses. We regret that we will not be able to continue all of these activities in 2010. Certainly this is no reflection on NMSU's support of our Teaching Academy. We continue to receive accolades and encouragement from the president's and provost's offices, as well as deans, department heads, and faculty. However, the reality is that our budget has been cut by a full $30 \%$.

Our donor giving makes up $25 \%$ of our total budget. If we can increase this, we might be able to reinstate some of these valuable activities. We hope that you will consider augmenting our resources by adding to your contribution. We are including a payroll deduction form for you, should you choose to do so. We hope you will.

making such visits may want to team with a teaching center board member, a committed donor or volunteer, or a member of the university advancement staff (Schneiter, 1985). Panas (2002) describes how to make a personal request, word by word and step by step.

\section{Pitches at Workshops}

Another successful way to seek gifts is to have donors give pitches at workshops. We arrange such pitches at about one workshop per month (Warwick, 2009). We provide the donors with sample scripts but encourage them to give testimony from the heart (Reid, 1998). These testimonies are very productive: at the end of one week-long workshop, four out of twelve of the participants made pledges. 


\section{Friends Luncheons}

Friends Luncheons are conducted in a group setting, and guests have included local legislators, emeriti faculty, representatives of community organizations, and university donors. The purpose of these events is fundraising as well as friend raising. Teaching Academy leadership and members explain the work of the center and provide testimonials about how the center has affected them. We present the need for funding tactfully, following up in writing and personally with the most promising donors. The results have included greater public awareness of the center and gifts ranging from five hundred to a thousand dollars to the exceptional six-figure planned gifts directed to the Teaching Center's endowment (Schumacher \& Seiler, 2003).

\section{The Gala}

The close of the school year, as well as the conclusion of the center's annual cycle of activity, is marked by the NMSU Teaching Academy's annual gala, Champagne and Chocolate. The gala is a celebration that also serves as a high point for donor solicitation and recognition. On our guest list are all Teaching Academy members and donors for the current year, special awardees, department heads, and deans, as well as the president and provost. The gala is well publicized, as we never miss an opportunity to see ourselves in print.

The gala was not initially conceived as a fundraising event, but we now send a personalized solicitation letter (Exhibit 19.4) one month prior to the event reminding members that "your name can be here" in our gala program. In addition, we send personalized e-mail reminders to some of our most active members just before the printing deadline for the gala poster and program. Gala solicitations have proved to be among our most successful: members are eager to be recognized as donors at the event. Our e-mail response rate has been as high as 20 percent. Those who cannot give frequently write with accolades.

\section{Recognizing Donors}

Fundraising efforts do not stop once a gift is received. Donor recognition is an important part of the fundraising effort and can encourage repeat and increased giving (Sargeant \& Jay, 2004). Recognition activities contain the same message as our solicitations: that giving to the NMSU Teaching Academy is important. It is also persuasive when members see 


\section{Exhibit 19.4 E-Mail Solicitation}

Congratulations on earning a membership at the Teaching Academy this year!

Allow me to introduce myself: I'm the Teaching Academy advancement officer. I want to personally invite you to consider donating to the NMSU Teaching Academy. Your contribution would help us continue to offer the programming you are used to. Our donors help provide the Center with more than $25 \%$ of its resources-an especially valuable form of support in these difficult budgetary times.

Our payroll deduction levels are as follows:

Founders: $\$ 25.00$ or more per pay period

Builders: $\$ 10.00$ or more per pay period

Backers: $\$ 5.00$ or more per pay period

We would love to include you among our donors. To have your name listed on our wall of honor and in the Gala program, we would need to hear back from you by April 19. You need only email us a response at this time, and we will then send you a payroll deduction form. Thanks for your consideration.

their peers and leaders giving. Donors are listed in newsletters by giving categories and invited to special events. Of course, a few donors desire little or no recognition, but most welcome mention of their giving.

We purposely err on the side of overrecognition. The NMSU Teaching Academy sends immediate thanks by a hand-written card from the advancement officer, as well as a formal letter (Exhibit 19.5) and an e-mail, both signed by the director and processed by an administrative assistant. The center maintains a prominent wall of honor in its classroom and on its website. Donors are recognized at the annual gala, where they wear special name tag ribbons, receive mention in the program, and are asked to stand as a group. In addition, all donors are invited to a group or individual lunch with the director, depending on the size of their gift. Donors are thanked as well by the university foundation in the same way as are all other university donors.

More than any other form of recognition, it is vitally important that any fundraising program ensures that funds raised for a stated purpose are used for that purpose. Professionals are bound to the Donor Bill of Rights, 1993, developed collaboratively by the Association of Fund-Raising Counsel, Association for Healthcare Philanthropy, Council for Advancement and Support of Education, and Association of Fundraising Professionals (Fischer, 2000). 


\section{Exhibit 19.5 Recognition Letter}

Thank you so much for your personal support of the Teaching Academy. Your gifts enable us to purchase library materials, support short courses, provide scholarships to teaching conferences, and bring nationally known speakers to our Academy. Your generosity also sustains the spirits of all of us who work for this fine organization.

As you well know, our Teaching Academy mission is to provide training, networking and mentoring to all NMSU University educators in an effort to support teachers, enhance learning, and build community. We help you and your colleagues develop extraordinary teaching lives embedded in exceptional careers. All members of the university community, especially NMSU students, benefit.

You are joined by more than one hundred colleagues who have also committed their support to the Teaching Academy. The world is a better place because of generosity. We thank you for being a cheerful giver!

Fundraisers who subscribe to such organizations as the Association of Fundraising Professionals are obligated to adhere to this organization's code of ethics. The purpose of these codes is to ensure fidelity to the donor's intent. Although gifts to the NMSU Teaching Academy are unrestricted, they are intended to benefit five broad areas: national speakers, teaching scholarships, short courses taught by center staff, teaching books and equipment, and endowment. We spend these funds accordingly and communicate our allocations in donor correspondence.

\section{Limitations}

Inevitably a fundraising program will encounter challenges and limitations.

\section{Staffing}

Allocating staffing is one of the most significant challenges facing the startup advancement program. Often a limitation at teaching centers, time and effort are precious resources. Nonetheless, there are several feasible models for assigning the fundraising task to professionals, including ours.

Some of the work of fundraising is shared by the director and administrative assistant of the center, but most is done by a designated advancement officer. The advancement officer plans and implements the fundraising program, manages the solicitation of individual gifts, coordinates efforts with other members of the university foundation fundraising 
team, and generates awareness of the center through publications and special events.

A faculty developer can serve in the role of advancement officer, and so can a graduate assistant. The advancement officer can be an additional staff member paid for by the teaching center. Alternatively, the university advancement office might assign one of its staff to oversee the teaching center's fundraising, with or without cost to the center. We decided to hire a quarter-time dedicated advancement officer because we felt that our new program would benefit from the guidance of a fundraising professional (Weinstein, 2009). In the beginning, we used ten hours a week of the advancement officer's time; now that the program is established, we use only five hours a week. In this way, our fundraising effort has become self-sustaining, raising more funds than it costs by a factor of four to one.

Resources available to the advancement officer include colleagues who have participated in fundraising and professionals in university advancement (Barbato \& Furlich, 2000). The advancement officer could also garner guidance and peer support from professional fundraising organizations such as the Association of Fundraising Professionals or Council for the Advancement and Support of Education. Among the highly recommended print resources for fundraising are Greenfield (2002), Lowenstein (1997), Panas (2002), and Weinstein (2009).

\section{Institutional Considerations}

Because of institutional considerations, not every element of our comprehensive fundraising program may fit another faculty development unit. Some centers may be too small or too new to contemplate an aggressive fundraising effort. Faculty developers may be uncomfortable becoming part-time advancement officers or may not have time. However, our experience has been that many of these objections are more perceived than real. Often they can be overcome by taking the consensus-building step of creating a fundraising plan, including a case statement.

Other teaching centers may be explicitly discouraged from fundraising by their university advancement office. While some campuses (ours included) encourage decentralized fundraising, others take a more centralized approach (Hecht, 2008). A teaching center fundraising effort would function best in a large institution that already has a strong and established advancement office with many potential donors. Otherwise the teaching center would be perceived as being in competition for the same few donors. We argue that our efforts augment, rather than detract 
from, the university's overall fundraising picture: our Teaching Academy donors have given above and beyond what they may give for other university purposes.

\section{Fundraising in Difficult Economic Times}

Centers should not be dissuaded from fundraising by a depressed economic climate or curtailed budgets. Many charities (ours included) are raising as much as or more than they did before 2008 (Holcomb, 2009). Jaschik (2011) reports that charitable contributions to all colleges and universities increased by a modest 0.5 percent from 2009 to 2010. Among research/doctoral institutions, private universities saw an increase of 1.5 percent, and public universities showed an increase of 5.1 percent. Indeed, if a teaching center is facing budget cutbacks, fundraising may well be the answer to bridge the gap (Warwick, 2009). There are several valuable strategies for fundraising in challenging times (Klein, 2009). Our 2009 appeal to donors (see Exhibit 19.3) conveyed a message of the impact of budget cuts on our center and asked for increased giving, without adopting the tone of appearing ungrateful for the university's core support. This same letter was sent in a slightly different form to NMSU Teaching Academy members who were not donors. Both letters had a positive response.

\section{Results}

The NMSU Teaching Academy was reinvented from a previous faculty development unit that had fallen on hard times. We believed that the enthusiasm generated by its reinvigoration in 2003 would result in gifts, so we took a calculated risk in 2004 by hiring a part-time advancement officer who worked ten hours a week, funded by an open budget line created by the retirement of a staff member. The university's foundation supported the initiative and asked the Teaching Academy to prepare a one-page case statement to be included in the university's $\$ 150$ million comprehensive campaign. The advancement officer drafted the case statement, created giving categories, and began personally visiting Teaching Academy members deemed most receptive to giving. Shortly after, mailings were sent to all Teaching Academy members. Our calculated gamble proved successful; in 2004, the Teaching Academy received eighteen payroll deduction gifts totaling $\$ 8,000$, and in 2010 it received over 100 payroll deduction gifts totaling $\$ 30,000$. Through outreach events such as Friends Luncheons, the Teaching Academy reached out to community 
members, and as a result, it received an unsolicited bequest commitment of $\$ 300,000$. Two additional planned gifts followed, bringing the total to $\$ 375,000$. The NMSU Teaching Academy now has an endowment to secure its future.

\section{Conclusion}

As budget continues to be one of the biggest problems facing teaching centers, many centers need augmented resources for expanded offerings and endowment. We have garnered goodwill in its most tangible form: a source of ongoing revenue that constitutes nearly a third of our budget and costs only a quarter of what we raise. We have also secured the future by building a Teaching Academy endowment. We believe that our model can be adopted at other teaching centers in whole or in part. While we pursue all of the fundraising efforts we have outlined here, there is no reason that another teaching center cannot cherry-pick from our roster of activities. For example, developing a case statement establishes the need, creates good public relations, and fosters a climate for later giving. Engaging the awareness of the university advancement office brings attention to the teaching center's giving opportunities. Mailing just one annual solicitation letter makes fundraising more palatable for developers reluctant to make face-to-face solicitations. Recognizing donor names, such as on our wall of honor, generates curiosity and interest. Organizing small, intimate Friends Luncheons garners unexpected and unsolicited gifts. An annual celebration such as our gala not only culminates the year's good work but also recognizes donors in public. Finally, mentioning the center's activities in a newsletter or other communication generates pleasant surprises. You may already have donors waiting in the wings, but they may be unsure of how and when to give. Each of these elements of our plan provides the means to make their gifts.

The value of donor commitment extends beyond dollars; it is important to the survival of a unit in a time of extreme budgetary constraint. Donors are invested in the center because they have given money to it (Sargeant \& Jay, 2004). For example, in a period of severe budget cuts, a group of our faculty donors volunteered to approach the president's office with a message: cut our salaries, but do not cut our professional development!

A center's most natural donors are its participants, but they do not know how to give and have not been asked. A fundraising plan enumerates the steps needed to engage them, as well as other potential 
donors, from the larger community. The goal is to create an ongoing culture of giving.

Faculty members need well-honed skills. Teaching centers can and will do even more to support them, but they will need philanthropic help to augment the core support they receive from their parent institutions. Faculty developers are natural and enthusiastic communicators of their good work. Following the ideas we have outlined, this enthusiasm can be channeled into fundraising success.

\section{REFERENCES}

Ahern, T. (2007). How to write fundraising materials that raise more money. Medfield, MA: Emerson \& Church.

Ashton, D. (2004). The complete guide to planned giving. Quincy, MA: Ashton Associates.

Barbato, J., \& Furlich, D. (2000). Writing for a good cause. New York, NY: Fireside Books.

Fischer, M. (2000). Ethical decision making in fund raising. Hoboken, NJ: Wiley.

Gray, T., \& Conway, J. (2007). Build it [right] and they will come: Boost attendance at your teaching center by building community. Journal of Faculty Development, 21(3), 179-184.

Greenfield, J. M. (2002). Fundraising fundamentals: A guide to annual giving for professionals and volunteers (2nd ed.). Hoboken, $\mathrm{NJ}$ : Wiley.

Hecht, I.W.D. (2008). Fund-raising: A new world for department chairs. Effective Practices for Academic Leaders, 3(4), 4.

Holcomb, J. R. (2009). Continuing the good amid an economic crisis: Fund development advice for thriving during uncertain times. Fort Worth, TX: Holcomb \& Associates.

Jaschik, S. (2011, February 2). Not so full recovery. Inside Higher Ed. Retrieved from www.insidehighered.com/news/2011/02/02/ colleges_see_very_modest_growth_in_fund_raising

Klein, K. (2009). Reliable fund-raising in unreliable times: What good causes need to know to survive and thrive. San Francisco, CA: Jossey-Bass.

Lowenstein, R. L. (1997). Pragmatic fund-raising for college administrators and development officers. Gainesville: University Press of Florida.

Panas, J. (2002). Asking: A 59-minute guide to everything board members, volunteers, and staff must know to secure the gift. Medfield, MA: Emerson \& Church.

Pitman, M. A. (2007). Ask without fear! A simple guide to connecting with what matters to them most. Mechanicsburg, PA: Executive Books. 
Reid, G. (1998). Engaging the faculty: A university science professor recommends getting his colleagues in deep with fund-raising programs. Fund Raising Management, 29(5), 32-33, 42.

Sargeant, A., \& Jay, E. (2004). Building donor loyalty: The fundraiser's guide to increasing lifetime value. San Francisco, CA: Jossey-Bass.

Schneiter, P. H. (1985). The art of asking: How to solicit philanthropic gifts. Rockville, MD: Taft Group.

Schumacher, E. C., \& Seiler, T. L. (2003). Building your endowment. San Francisco, CA: Jossey-Bass.

Warwick, M. (2009). Fundraising when money is tight; A strategic and practical guide to surviving tough times and thriving in the future. San Francisco, CA: Jossey-Bass.

Weinstein, S. (2009). The complete guide to fundraising management. Hoboken, NJ: Wiley. 